Jurnal Ekonomi, Bisnis dan Akuntansi (JEBA) Volume 21 Nomor 04 Tahun 2019

\title{
MODEL PENERIMAAN TEKNOLOGI MOBILE PAYMENT PADA DIGITAL NATIVE DAN DIGITAL IMMIGRANT DI INDONESIA
}

\author{
Yordan Hermawan Apidana ${ }^{1 *}$, Agus Suroso ${ }^{1}$, Refius Pradipta Setyanto ${ }^{1}$ \\ 1Program Pascasarjana Magister Manajemen Universitas Jenderal Soedirman Purwokerto \\ ${ }^{*}$ Email corresponding author: yordanhermawan@gmail.com
}

\begin{abstract}
Abstrak
Penelitian ini merupakan penelitian survei pada pada pengguna mobile payment di Indonesia yang terbagi menjadi 2 kelompok yaitu kelompok generasi digital native dan digital immigrant. Tujuan dari penelitian ini yaitu untuk mengetahui pengaruh perceived usefullness, perceived ease of use, trust, perceived risk, social influence terhadap behavioral intention to reuse pada generasi digital native dan generasi digital immigrant. Jumlah responden dalam penelitan ini adalah 214 responden. Dalam penelitian ini sampel diambil dengan cara nonprobability sampling yaitu dengan teknik purposive sampling. Pengumpulan data yang digunakan dalam penelitian ini adalah dengan menggunakan kuesioner secara daring melalui Google Form. Sedangkan alat analisis dalam penelitan ini menggunakan Structural equation modeling (SEM). Berdasarkan hasil penelitian dan analisis data menunjukan bahwa : (1) Perceived usefullness berpengaruh positif terhadap behavioral intention to reuse (2) Pengaruh perceived usefullness terhadap behavioral intention to reuse mobile payment pada digital native lebih kuat daripada digital immigrant (3) Perceived ease of use berpengaruh positif terhadap perceived usefullness (4) Perceived ease of use berpengaruh positif terhadap behavioral intention to reuse (5) Perceived ease of use berpengaruh positif terhadap trust (6) Perceived ease of use terhadap behavioral intention to reuse mobile payment pada digital native lebih kuat daripada digital immigrant (7) Trust berpengaruh positif terhadap perceived usefullness (8) Trust berpengaruh positif terhadap behavioral intention to reuse (9) pengaruh trust terhadap behavioral intention to reuse mobile payment pada digital native lebih kuat daripada digital immigrant (10) Perceived risk berpengaruh negatif terhadap trust (11) Perceived risk berpengaruh negatif terhadap behavioral intention to reuse mobile payment (12) Perceived risk terhadap behavioral intention to reuse mobile payment pada digital native lebih kuat daripada digital immigrant (13) Social influence berpengaruh positif terhadap behavioral intention to reuse (14) pengaruh social influence terhadap behavioral intention to reuse mobile payment pada digital native lebih kuat daripada digital immigrant.
\end{abstract}

Kata Kunci: Technology Acceptance Model (TAM), Perceived Usefullness, Perceived Ease of Use, Trust, Perceived Risk Social Influence Behavioral Intention to Reuse, Digital Native, Digital Immigrant

\section{Abstract}

This research is a survey research on mobile payment users in Indonesia and divided into 2 groups, namely digital native generation and digital immigrant groups. The purpose of this study is to determine the effect of perceived usefulness, perceived ease of use, trust, perceived risk, social influence on behavioral intention to reuse in digital native generation and digital immigrant generation. The number of respondents in this study were 214 respondents. In this study the sample was taken by means of nonprobability sampling, namely by purposive sampling technique. Data collection used in this research is to use a questionnaire online through Google Form. While the analysis tools in this research use Structural equation modeling (SEM). Based on the results of research and data analysis shows that: (1) Perceived usefulness has a positive effect on behavioral intention to reuse (2) The effect of perceived usefulness on behavioral intention to reuse mobile payment on digital native is stronger than digital immigrant (3) Perceived usefulness has a positive effect positive for perceived usefulness (4) Perceived ease of use has a positive effect on behavioral intention to reuse (5) Perceived ease of use has a positive effect on trust (6) Perceived ease of use of behavioral intention to reuse mobile payment on native digital is stronger than digital immigrant (7) Trust has a positive effect on perceived usefulness (8) Trust has a positive effect on behavioral intention to reuse (9) The effect of trust on behavioral intention to reuse mobile payment on digital native is stronger than digital immigrant (10) Perceived risk has a negative effect on trust (11) Perceived risk holds negative influence on behavioral intention to reuse mobile payment (12) Perceived risk of behavioral intention to reuse mobile payment on digital native is stronger than digital immigrant (13) Social influence has a positive effect on behavioral intention to reuse (14) the influence of social influence on behavioral intention to reuse mobile payment on digital native is stronger than digital immigrant.

Keywords: Technology Acceptance Model (TAM), Perceived Usefullness, Perceived Ease of Use, Trust, Perceived Risk Social Influence Behavioral Intention to Reuse, Digital Native, Digital Immigrant 


\section{PENDAHULUAN}

Perkembangan era teknologi informasi telah mempengaruhi banyak bidang salah satunya adalah dalam bidang ekonomi. Contoh perkembangan bidang ekonomi yang dipengaruhi teknologi informasi adalah hadirnya e-money (electronic money). Jumlah uang elektronik maupun jumlah transaksi uang elektronik dari tahun ke tahun di Indonesia semakin berkembang. Bank Indonesia pada tahun 2018 mengeluarkan data yang menunjukan perkembangan jumlah uang elektronik pada tahun 2011 sebesar 14,2 juta yang kemudian meningkat menjadi 135,8 juta pada tahun 2018. Dan perkembangan jumlah transaksi uang elektronik dari sebesar 40,6 juta pada tahun 2011, meningkat sebesar 1,7 milyar transaksi pada tahun 2018. Dahlberg et al. (2008) mendefinisikan mobile payment sebagai pembayaran untuk barang jasa dan tagihan menggunakan perangkat mobile menggunakan jaringan nirkabel dan teknologi komunikasi lainnya. Di Indonesia sendiri dengan meningkatnya penetrasi trend smartphone dan masyarakat nir-kas (cashlees society) memberikan potensi yang besar untuk mengembangkan sistem pembayaran dengan mobile payment ini. Sejak tahun 2012 layanan mobile payment di Indonesia mulai beragam, industri perbankan dan pengembang aplikasi mulai masuk di dalamnya. Pemerintah Indonesia sendiri pada 14 Agustus 2014 mulai mencanangkankan Gerakan Nasional Non Tunai (GNNT) melalui penandatanganan nota kesepahaman antara Bank Indonesia dengan Kementerian Koordinator Bidang Perekonomian, Kementerian Keuangan, pemerintah daerah, serta Asosiasi Pemerintah Provinsi Seluruh Indonesia.

Gerakan ini diharapkan mampu meningkatkan kesadaran masyarakat bahwa pembayaran nontunai lebih praktis, efisien, dan aman. Jika komunitas dan gaya hidup nontunai ini sudah meluas, maka beban bank sentral dalam mencetak serta mengendalikan peredaran uang di masyarakat akan berkurang. Pada Tahun 2018 JAKPAT melakukan survei untuk memprediksi tren sistem pembayaran digital di Indonesia. Hasil survei tersebut menjelaskan bahwa responden kedepannya berencana menggunakan sistem pembayaran digital lebih sering lagi untuk membeli kebutuhan sehari-hari mereka. Survei JAKPAT yang melibatkan responden sebanyak 1896 di seluruh wilayah Indonesia juga menyebutkan bahwa GoPay, mobile banking, OVO dan T-Cash (LinkAja) merupakan sistem pembayaran digital yang paling populer saat ini.

Terlepas dari kepopuleran dan manfaat GoPay, Mobile Banking dan OVO saat ini sebagai alat pembayaran daring, adopsi penggunaan layanan mobile payment di Indonesia masih sangat rendah. Data survei dari MasterCard Mobile Payment Readiness Index (MMPRI) pada tahun 2012 menunjukan Indonesia menempati posisi ke-33 dari 34 negara dengan kesiapan penggunaan mobile payment. Konsumen di Indonesia berada di bawah rata-rata dalam kaakraban, frekuensi dan kemauan menggunakan mobile payment. Pada tahun 2017 MDI Ventures bekerjasama dengan Mandiri Sekuritas merilis sebuh riset bertajuk Mobile Payments in Indonesia: Race to Big Data Domination, dalam riset tersebut menunjukan bahwa penetrasi smartphone di Indonesia pada tahun 2012 sampai dengan 2017 sebesar 110\%, sedangkan penetrasi e-money pada tahun 2012 sampai dengan 2017 hanya sebesar 35\%. Hal ini menunjukan bahwa meskipun terjadi peningkatan pengguna smarthphone, pengguna e-money di Indonesia masih sangat rendah.

Penggunaan teknologi mobile payment secara teori seharusnya lebih praktis dan memberikan kemudahan bagi penggunanya. Namun, penerimaan suatu teknologi mungkin berbeda bagi setiap generasi. Generasi Digital Native (istilah untuk orang yang lahir pada era digital) memandang bahwa suatu teknologi baru mudah digunakan, sedangkan pada generasi Digital Immigrant (istilah untuk orang yang lahir era pre-computer world) mungkin merasa bahwa suatu teknologi atau penemuan baru sulit mereka terima (Zur et al., 2011). Menurut Prensky (2001) dalam Istiana (2016) digital native adalah generasi digital yang sangat paham dengan internet, multitasking, dan technologically literate. Mereka ingin cepat dalam menelusur informasi dan selalu tersambung dengan internet. Mereka sangat menyukai sumber-sumber informasi dalam bentuk digital. Mereka sembarangan dalam mengakses informasi (random access to information) dan menyukai fun learning. Lebih lanjut dapat disebutkan karakteristik dari digital native adalah: mereka berada dalam dunia media dan gadgets terkait teknologi informasi, teknologi yang mereka gunakan mobile internet menjadi bagian dari dunia mereka, 
mereka multitaskers, mereka siap dengan perubahan besar teknologi bahkan untuk 10 tahun mendatang.

Generasi digital native menganggap bahwa teknologi digital sebagai bagian dari kehidupan yang tidak terpisahkan darinya (Mardiana, 2011). Sedangkan istilah Digital immigrant menurut Harding (2010) dalam Zur (2011) mengacu pada mereka yang lahir dan tumbuh pada era perkembangan dunia komputer. Pada generasi digital native mereka terampil dalam bahasa komputer dan budaya WEB karena mereka hidup didalamnya, sedangkan pada generasi digital immigrant secara natural mereka lebih kesulitan.

\section{TINJAUAN PUSTAKA}

\section{Technology Acceptance Model (TAM)}

Davis mengembangkan Model TAM pada tahun 1986. TAM merupakan salah satu jenis teori yang menggunakan pendekatan teori perilaku (behavioral theory) yang banyak digunakan untuk mengkaji proses adopsi teknologi informasi. Menurut Davis et. al. (1989) konsep Technology Acceptance Model (TAM), merupakan sebuah teori yang menawarkan landasan untuk mempelajari dan memahami perilaku pemakai teknologi dalam menerima dan menggunakan teknologi yang ditawarkan. Model TAM dikembangkan dari teori psikologis, yang menjelaskan perilaku pengguna teknologi dengan berlandaskan pada kepercayaan (belief), sikap (attitude), keinginan (intention), dan hubungan perilaku pengguna (user behavior relationship). Jogiyanto (2007) TAM merupakan model perilaku (behavior) yang bermanfaat untuk menjawab pertanyaan mengapa banyak sistem teknologi informasi gagal diterapkan karena pemakainya tidak mempunyai niat (intention) untuk menggunakannya, dibangun dengan dasar teori yang kuat, telah diuji dengan banyak penelitian dan hasilnya sebagian besar mendukung dan menyimpulkan bahwa TAM merupakan model yang baik. Kelebihan TAM yang paling penting adalah model ini merupakan model yang parsimoni yaitu model yang sederhana tetapi valid. TAM menjelaskan secara sederhana hubungan sebab akibat antara perilaku dan keyakinan (manfaat suatu sistem informasi dan kemudahan), tujuan, serta penggunaan aktual dari pengguna sistem informasi. Penjelasan tersebut sesuai dengan tujuan penelitian ini yaitu untuk menguji pengaruh Technology Acceptance Model yang menentukan sikap konsumen dalam memutuskan untuk mengadopsi layanan mobile payment. Selain itu TAM diyakini mampu meramalkan penerimaan pemakai terhadap teknologi berdasarkan dampak dari dua faktor, yaitu persepsi kemanfaatan (perceived usefullness) dan persepsi kemudahan pemakaian (perceived ease of use) (Davis, 1989).

\section{Persepsi Kemudahan Penggunaan (Perceived Ease of Use)}

Davis (1989) menyatakan bahwa persepsi kemudahan penggunaan (perceived ease of use) merupakan sebuah tingkatan dimana seseorang percaya bahwa penggunaan sistem tertentu, mampu mengurangi beban usaha dirinya dalam mengerjakan sesuatu. Frekuensi penggunaan dan interaksi antara pengguna (user) dengan sistem juga mampu menunjukan kemudahan penggunaan. Sistem yang lebih sering digunakan menunjukan bahwa sistem tersebut lebih dikenal, lebih mudah dioperasikan dan lebih mudah digunakan oleh penggunanya. Davis (1989) memberikan beberapa indikator dari perceived ease of use: mudah dipelajari/dipahami (ease of learn), dapat dikontrol (controllable), jelas dan dapat dipahami (clear and understandable), fleksibel (flexible), mudah untuk menjadi terampil (easy to become skillful), mudah digunakan (ease to use).

\section{Persepsi Kegunaan (Perceived Usefullness)}

Persepsi kegunaan (perceived usefullness) didefinisikan sebagai suatu ukuran dalam penggunaan suatu teknologi dipercaya akan mendatangkan manfaat bagi orang yang menggunakannya (Davis, 1989 dan Davis, 1993). Davis (1989) menyatakan persepsi terhadap 
kegunaan sebagai kemampuan subjektif para pengguna untuk masa yang akan datang dimana dengan menggunakan sistem aplikasi yang spesifik akan meningkatkan kinerja dalam konteks organisasi. Thompson et. al. (1991) dalam Gafen et al (2003) kemudian mengemukakan kesimpulan bahwa kemanfaatan teknologi informasi merupakan dampak yang diharapkan oleh pengguna teknologi informasi dalam menjalankan tugas mereka. Thompson dan Howell (1991) dalam Gafen et al (2003) juga menyatakan bahwa individu akan menggunakan teknologi informasi, jika orang tersebut memiliki pemahaman mengenai manfaat atau kegunaan (usefullness) yang baik atas kegunaannya. Perceived usefullness (persepsi kegunaan penggunaan) merupakan salah satu poin dalam model TAM, yang telah diuji dalam penelitian Davis (1989).

\section{Persepsi Resiko (Perceived Risk)}

Perceived Risk didefinisikan secara umum sebagai perasaan keridakpastian tentang kemungkinan adanya konsekuensi negatif dari penggunaan produk atau layanan (Featerhman dan Pavlou, 2003). Featherman dan Pavlou (2003) melakukan investigasi lebih lanjut terhadap perceived risk dan membaginya kedalam tujuh aspek risk. Tujuh aspek risk yang diteliti adalah performance, financial, time, psychological, social, privacy, and overall risk didalam konteks $e$ service adoption. Persepsi resiko dibentuk oleh privasi, keamanan dan kepercayaan. Persepsi resiko dipandang sebagai ketidakpastian digabungkan dengan hasil dari suatu keputusan. (Gafen et al 2003). Sedangkan menurut Gafen et al (2003) Risiko merupakan faktor pendahulu yang memperoleh kepercayaan. Di dalam transaksi daring, setidaknya ada tiga macam risiko yang mungkin terjadi yaitu risiko produk, risiko transaksi dan risiko psikologis (Suresh A.M. dan Shashikala R. 2011).

\section{Kepercayaan (Trust)}

Lee (2009) berpendapat bahwa, kepercayan adalah yakin terhadap orang lain dengan harapan orang lain tidak akan berperilaku oportunis. Ini merupakan keyakinan bahwa pihak lain akan berperilaku sesuai etika sosial dan terdapat keyakinan bahwa pihak yang dipercaya akan memenuhi komitmen. Kepercayan merupakan sebuah pondasi dari bisnis karena transaksi bisnis antara dua pihak atau lebih akan terjadi apabila masing-masing saling mempercayai.

Gafen (2000) mendefinisikan kepercayaan adalah kemauan untuk membuat dirinya peka pada tindakan yang diambil oleh orang yang dipercayainya berdasarkan rasa kepercayaan dan tanggung jawab. Dengan demikian, kepercayan terhadap teknologi informasi merupakan kepercayan sentral yang dibentuk dan dipengaruhi oleh faktor-faktor individual, sosial, dan instiusional.

\section{Pengaruh Sosial (Social Influence)}

Jogiyanto (2007) mendefinisikan pengaruh sosial (social influence) sebagai sejauh mana seorang individual mempersepsikan kepentingan yang dipercaya oleh orang-orang lain yang akan mempengaruhinya menggunakan sistem yang baru.). Venkatesh et al. (2003) menyatakan bahwa pada lingkungan tertentu, penggunaan teknologi informasi akan meningkatkan status (image) seseorang di dalam sistem sosial. Menurut Venkatesh dan Davis (2000), pengaruh sosial mempunyai dampak pada perilaku individual melalui tiga mekanisme yaitu ketaatan (compliance), internalisasi (internalization), dan identifikasi (identification). Dapat disimpulkan bahwa semakin banyak pengaruh yang diberikan sebuah lingkungan terhadap calon pengguna teknologi informasi untuk menggunakan suatu teknologi informasi yang baru maka semakin besar minat yang timbul dari personal calon pengguna tersebut dalam menggunakan teknologi informasi tersebut karena pengaruh yang kuat dari lingkungan sekitarnya. Menurut Sangadji 
(2013) social influence atau pengaruh sosial, termasuk kedalam major influence in consumer decision process. Perilaku konsumen juga akan dipengaruhi oleh masyarakat atau faktor sosial yang melingkarinya. Pengaruh sosial akan menjadi bahan pertimbangan konsumen dalam menentukan minat beli dankeputusan untuk membeli produk. Sangadji (2013) mengemukakan bahwa terdapat empat indikator yang terdapat didalam pengaruh sosial, yaitu :

a. Rules atau peraturan dalam kelompok sosial konsumen atau calon pembeli tersebut.

b. Family atau pengaruh keluarga dari konsumen.

c. Reference group atau kelompok yang menjadi panutan dan referensi dari konsumen.

d. Culture . atau kelas sosial dan budaya yang dianut oleh konsumen dan calon pembeli.

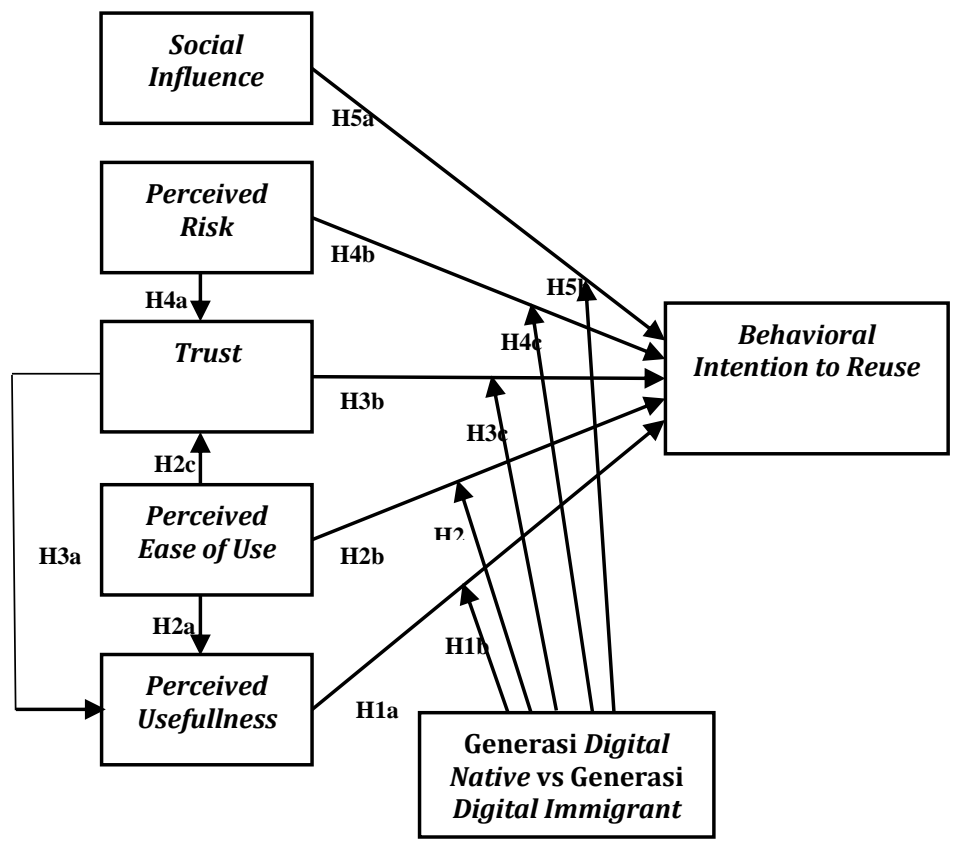

Gambar 1. Model Penelitian

\section{Hipotesis}

Hipotesis dalam penelitian ini berdasarkan rumusan masalah, tinjauan pustaka dan penelitian terdahulu adalah :

H1a: Perceived usefullness berpengaruh positif terhadap behavioral intention to reuse mobile payment.

H1b: Pengaruh perceived usefullness terhadap behavioral intention to reuse mobile payment pada Digital Native lebih kuat daripada Digital Immigrant

H2a: Perceived ease of use berpengaruh positif terhadap perceived usefullness

H2b: Perceived ease of use berpengaruh positif terhadap behavioral intention to reuse mobile payment

H2c: Perceived ease of use berpengaruh positif terhadap trust

$\mathrm{H} 2 \mathrm{~d}$ : Pengaruh perceived ease of use terhadap behavioral intention to reuse mobile payment pada Digital Native lebih kuat daripada Digital Immigrant.

H3a: Trust berpengaruh positif terhadap perceived usefullness

H3b: Trust berpengaruh positif terhadap behavioral intention to reuse mobile payment. 
H3c: Pengaruh trust terhadap behavioral intention to reuse mobile payment pada Digital Native lebih kuat daripada Digital Immigrant.

H4a: Perceived risk berpengaruh negatif terhadap trust

H4b: Perceived risk berpengaruh negatif terhadap behavioral intention to reuse mobile payment.

H4c: Pengaruh perceived risk terhadap behavioral intention to reuse mobile payment pada Digital Native lebih kuat daripada Digital Immigrant.

H5a: Social influence berpengaruh positif terhadap behavioral intention to reuse mobile payment. H5b: Pengaruh sosial influence terhadap behavioral intention to reuse mobile payment pada Digital Native lebih kuat daripada Digital Immigrant.

\section{METODE PENELITIAN}

Populasi yang digunakan dalam penelitian ini adalah seluruh pengguna mobile payment di Indonesia. Jumlah pengguna mobile payment di Indonesia tidak diketahui jumlahnya karena belum ada data yang mendukung mengenai jumlah secara pasti pengguna mobile payment di Indonesia.

Dikarenakan jumlah populasi penngguna mobile payment di Indonesia tidak diketahui, penentuan basarnya sampel berpedoman pada rumus berikut :

$$
\begin{aligned}
& E=1,96\left[\frac{1-P}{N}\right] \\
& P=P(1-P)\left[\frac{1.96}{e}\right]^{2}
\end{aligned}
$$

Keterangan :

$\mathrm{E}=$ Eror

$\mathrm{P}=$ Proporsi populasi

$\mathrm{N}=$ Jumlah sampel

Menurut Djarwanto (2005) jika proporsi populasi tidak diketahui maka dapat menggunakan $\mathrm{P}$ maksimum. Besarnya $\mathrm{P}$ antara 0 dan 1 maka $\mathrm{P}$ maksimal adalah $\mathrm{F}(\mathrm{P})=\mathrm{P}-\mathrm{P}_{2}$ atau sebesar 0,5 maka besarnya sampel minimal yang dapat diambil adalah :

$\mathrm{N}=0,25 \quad\left[\frac{1,96}{0,50}\right]^{2}=96,04$

(Dibulatkan menjadi 100 sampel)

Dengan batas minimal pengambilan sempel diatas sebesar 100 sampel. Maka dalam penelitian ini peneliti menggunakan sampel sebesar 200 responden, dengan pembagian 100 sampel untuk responden kategori digital native dan 100 sampel untuk responden kategori digital immigrant.

Dalam penelitian ini sampel diambil dengan cara nonprobability sampling yaitu dengan teknik purposive sampling. Menurut Suliyanto (2018) nonprobability sampling merupakan teknik pengambilan sampel di mana tiap anggota populasi tidak mempunyai kesempatan yang sama untuk dijadikan sampel. Sedangkan purposive sampling menurut Suliyanto (2018) merupakan metode pemilihan sampel dengan berdasarkan pada kriteria-kriteria tertentu. Penenentuan kriteria-kriteria tertentu ini dimaksudkan agar dapat memberikan informasi yang masksimal. Kriteria dari sampel ini adalah orang yang pernah menggunakan atau bertransaksi menggunakan mobile payment yamg berumur 18 tahun sampai dengan 35 yang masuk ke dalam kelompok 
digital native dan 35 tahun sampai dengan 50 tahun yang masuk ke dalam kelompok digital immigrant. Pengumpulan data yang digunakan dalam penelitian ini adalah dengan menggunakan kuesioner secara daring melalui Google Form. Penyebaran dilakukan di media sosial, forum kampus dan orang-orang sekitar yang sudah pernah menggunakan mobile payment. Sedangkan alat analisis dalam penelitan ini menggunakan Structural equation modeling (SEM) dengan menggunakan software AMOS.

\section{Analisis Data}

\section{Evaluasi Kriteria Goodness-of-fit}

Pengujian kesesuaian model dilakukan melalui telaah terhadap kriteria goodness of fit yang meliputi goodness of fit: Chi-square, probabilitas, RMSEA, CMIN/DF, GFI, AGFI, TLI, CFI dan DF. Hasil perhitungan uji kesesuaian statistik model selengkapnya dapat dilihat pada Tabel 4.22.

\begin{tabular}{|c|c|c|c|}
\hline Goodness of fit index & Cut-of value & $\begin{array}{l}\text { Hasil } \\
\text { analisis }\end{array}$ & $\begin{array}{l}\text { Evaluasi } \\
\text { Model }\end{array}$ \\
\hline \multicolumn{4}{|l|}{ Kelompok Native } \\
\hline$X^{2}$-Chi-square & 86,79 & $37^{275,8}$ & Marginal \\
\hline Significancy probability & $\geq 0,05$ & 0,000 & Marginal \\
\hline RMSEA & $\leq 0,08$ & 0,061 & Baik \\
\hline GFI & $\geq 0,90$ & 0,811 & Marginal \\
\hline AGFI & $\geq 0,90$ & 0,757 & Marginal \\
\hline CMIN/DF & $\leq 2,00$ & 1,400 & Baik \\
\hline TLI & $\geq 0,95$ & 0,958 & Baik \\
\hline CFI & $\geq 0,95$ & 0,965 & Baik \\
\hline Goodness of fit index & Cut-of value & $\begin{array}{r}\text { Hasil } \\
\text { analisis }\end{array}$ & $\begin{array}{l}\text { Evaluasi } \\
\text { Model }\end{array}$ \\
\hline \multicolumn{4}{|l|}{ Kelompok Immigrant } \\
\hline$X^{2}$-Chi-square & 81,46 & $51^{273,4}$ & Marginal \\
\hline Significancy probability & $\geq 0,05$ & 0,000 & Marginal \\
\hline RMSEA & $\leq 0,08$ & 0,061 & Baik \\
\hline GFI & $\geq 0,90$ & 0,823 & Marginal \\
\hline AGFI & $\geq 0,90$ & 0,772 & Marginal \\
\hline CMIN/DF & $\leq 2,00$ & 1,388 & Baik \\
\hline TLI & $\geq 0,95$ & 0,953 & Baik \\
\hline CFI & $\geq 0,95$ & 0,960 & Baik \\
\hline
\end{tabular}

Tabel 1. Hasil Goodnees of Fit

\section{Chi square}

Model dikatakan baik jika nilai Chi-Square-nya rendah. Semakin kecil nilai Chi-Square semakin baik model itu dan diterima berdasarkan probabilitas dengan cut of value sebesar $\mathrm{P}>0,05$. Dalam penelitian ini nilai Chi-Square yang didapatkan untuk kelompok digital native adalah sebesar 275,837 dengan nilai $\mathrm{p}=0,000$ sedangkan nilai Chi-Square untuk kelompok digital immigrant adalah sebesar 273,451 dengan nilai $p=0,000$. Dengan demikian dapat disimpulkan bahwa 
model dalam penelitian ini termasuk kategori marginal baik untuk kelompok digital native maupun kelompok digital immigrant karena nilai p nya kurang dari 0.05.

\section{RMSEA - The Root Mean Square Error Of Approximation}

Nilai RMSEA yang < 0,08 menunjukkan sebuah close fit dari model itu berdasarkan degress of freedoom. Berdasarkan penelitian ini nilai RMSEA yang didapatkan untuk kelompok digital native dan kelompok digital immigrant memiliki nilai yang sama yaitu sebesar 0,061. Dengan demikian model ini termasuk a very good fit karena nilai RMSEA-nya kurang dari 0,08.

\section{GFI- Goodness of Fit Index}

Nilai GFI yang dihasilkan dalam penelitian ini adalah 0,811 untuk kelompok digital native dan 0,823 untuk kelompok digital immigrant. Nilai ini lebih kecil dari angka 0,90 sehingga termasuk kategori marginal.

\section{AGFI- Adjusted Goodness of Fit Index}

Tingkat penerimaan yang direkomendasikan adalah bila AGFI memiliki nilai sama dengan atau lebih besar dari 0,90. Nilai AGFI yang dihasilkan dalam penelitian ini adalah 0,757 untuk kelompok digital native dan 0,772 untuk kelompok digital immigrant. Nilai ini lebih kecil dari 0,90 sehingga termasuk kategori marginal.

\section{CMIN/DF-The Minimum Sample Discrepancy}

CMIN/DIF merupakan salah satu indikator untuk mengukur tingkat fitnya sebuah model. Dalam hal ini CMIN/DF tidak lain adalah statistik chi-square, $\chi^{2}$ dibagi DF-nya sehingga disebut $\chi^{2}$ relatif. Nilai $\chi^{2}$ relatif yang kurang dari 2.0 atau kurang dari 3.0 adalah indikasi dari acceptable fit antara model dan data . Nilai CMIN/DF model penelitian ini adalah sebesar 1,400 untuk kelompok digital native dan 1,388 untuk kelompok digital immigrant. Dengan demikian model ini termasuk a very good fit karena nilai CMIN/DF-nya kurang dari 2.0.

\section{TLI-Tucker Lewis Index}

Merupakan incremental index yang membandingkan sebuah model yang diuji terhadap sebuah baseline model, dimana nilai yang direkomendasikan sebagai acuan diterimanya sebuah model adalah $\geq 0,95$ dan nilai mendekati 1 menunjukkan a very good fit. Nilai TLI yang dihasilkan dalam penelitian ini adalah 0,958 untuk kelompok digital native dan 0,953 untuk kelompok digital immigrant. Berdasarkan kriteria TLI, maka nilai ini termasuk very good fit.

\section{CFI-Comparative Fit Index}

Nilai CFI yang dihasilkan dalam penelitian ini adalah 0,965 untuk kelompok digital native dan 0,960 untuk kelompok digital immigrant. Nilai ini lebih besar dari 0,95 sehingga termasuk very good fit.

\section{Structural Equation Modelling (SEM)}

Hasil pengolahan analisis structural equation modelling (SEM) dapat dilihat pada Gambar 4.1, Gambar 4.2 dan Tabel 4.23. 


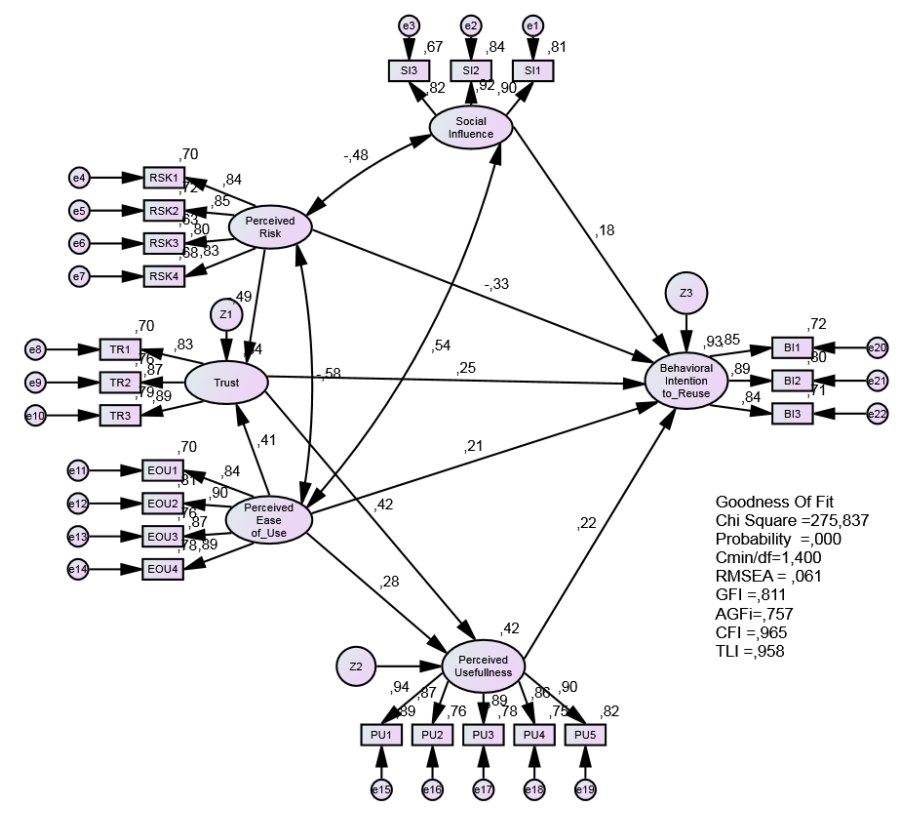

Gambar 2. Hasil analisis structural equation modelling kelompok generasi digital native

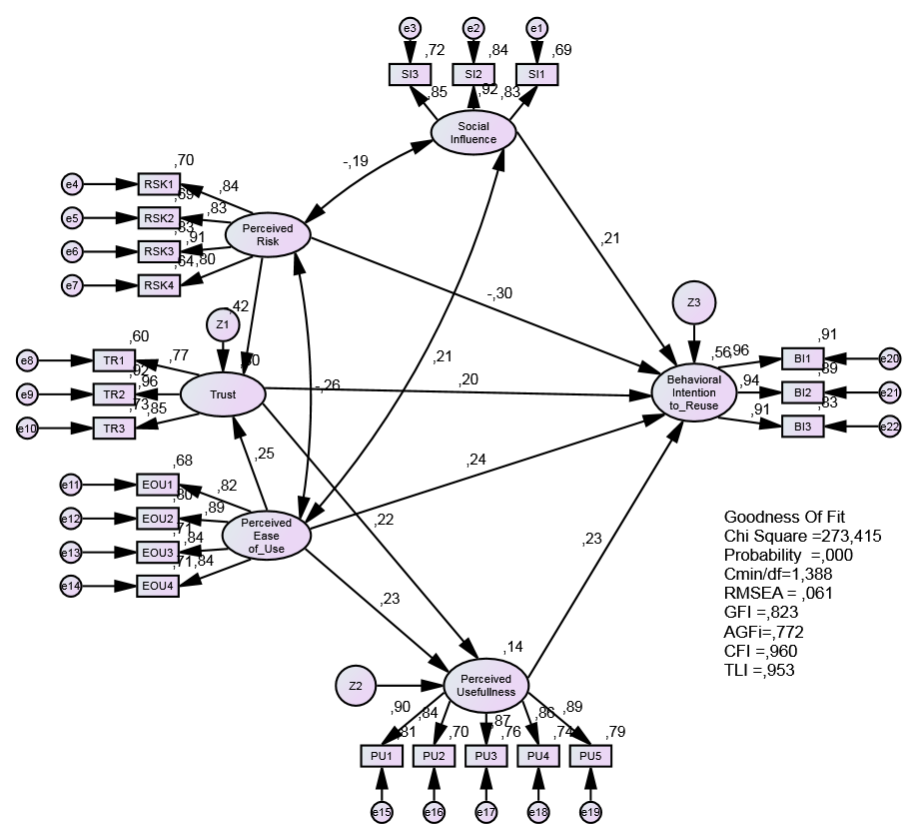

Gamber 3. Hasil analisis structural equation modelling kelompok generasi digital immigrant

\begin{tabular}{|c|c|c|c|c|c|c|}
\hline \multicolumn{3}{|c|}{ Kausalitas } & \multirow{2}{*}{ Estimate } & \multirow[t]{2}{*}{ S.E. } & \multirow[t]{2}{*}{ C.R. } & \multirow[t]{2}{*}{$\mathbf{P}$} \\
\hline Kelompok Digital Native & & & & & & \\
\hline Trust & $<<-$ & Perceived Risk & $-0,492$ & 0,100 & $-4,932$ & 0,000 \\
\hline Trust & $<--$ & Perceived Ease of Use & 0,420 & 0,097 & 4,319 & 0,000 \\
\hline Perceived Usefullness & $<--$ & Perceived Ease of Use & 0,297 & 0,130 & 2,284 & 0,022 \\
\hline Perceived Usefullness & $<--$ & Trust & 0,432 & 0,132 & 3,265 & 0,001 \\
\hline Behavioral Intention to Reuse & $<--$ & Trust & 0,246 & 0,097 & 2,523 & 0,012 \\
\hline Behavioral Intention to Reuse & $<--$ & Perceived Ease of Use & 0,218 & 0,077 & 2,838 & 0,005 \\
\hline Behavioral Intention to Reuse & $<--$ & Perceived Usefullness & 0,218 & 0,065 & 3,366 & 0,000 \\
\hline Behavioral Intention to Reuse & $<--$ & Social Influence & 0,151 & 0,055 & 2,759 & 0,006 \\
\hline Behavioral Intention to Reuse & $<--$ & Perceived Risk & $-0,331$ & 0,080 & $-4,138$ & 0,000 \\
\hline
\end{tabular}




\begin{tabular}{|c|c|c|c|c|c|}
\hline \multicolumn{2}{|c|}{ Kausalitas } & Estimate & S.E. & C.R. & $\mathbf{P}$ \\
\hline \multicolumn{6}{|c|}{ Kelompok Digital Native } \\
\hline \\
\hline \multicolumn{6}{|c|}{ Perceived_Usefullness : 0,422} \\
\hline \multicolumn{6}{|c|}{ Behavioral Intention to Reuse : 0,927} \\
\hline \multicolumn{2}{|c|}{$\begin{array}{ll}\text { Kausalitas } \\
\end{array}$} & Estimate & S.E. & C.R. & $\mathbf{P}$ \\
\hline \multicolumn{6}{|c|}{ Kelompok Digital Immigrant } \\
\hline Trust & $<--$ Perceived Risk & $-0,371$ & 0,093 & $-3,982$ & 0,000 \\
\hline Trust & $<-$ Perceived Ease of Use & 0,236 & 0,094 & 2,512 & 0,012 \\
\hline Perceived Usefullness & $<-$ Perceived Ease of Use & 0,257 & 0,122 & 2,104 & 0,035 \\
\hline Perceived Usefullness & $<--$ Trust & 0,263 & 0,127 & 2,074 & 0,038 \\
\hline Behavioral Intention to Reuse & $<--$ Trust & 0,236 & 0,110 & 2,140 & 0,032 \\
\hline Behavioral Intention to Reuse & $<-$ Perceived Ease of Use & 0,269 & 0,097 & 2,768 & 0,006 \\
\hline Behavioral Intention to Reuse & $<--\quad$ Perceived Usefullness & 0,240 & 0,085 & 2,816 & 0,005 \\
\hline Behavioral Intention to Reuse & $<--$ Social Influence & 0,214 & 0,082 & 2,622 & 0,009 \\
\hline Behavioral Intention to Reuse & <-- Perceived Risk & $-0,311$ & 0,097 & $-3,214$ & 0,001 \\
\hline \multicolumn{6}{|c|}{$\begin{array}{l}\text { Squared Multiple Correlations: } \\
\text { Trust : } 0,296 \\
\text { Perceived Usefullness : } 0,140 \\
\text { Behavioral Intention to Reuse : } 0,557\end{array}$} \\
\hline
\end{tabular}

\section{Tabel 2. Hasil analisis structural equation modelling}

\section{Pengujian Hipotesis}

Hipotesis H1a menyatakan "Perceived usefullness berpengaruh positif terhadap behavioral intention to reuse mobile payment.". Berdasarkan hasil analisis diketahui nilai estimasi koefisien jalur variabel perceived usefullness terhadap behavioral intention to reuse mobile payment untuk kelompok digital native sebesar 0,218 dengan nilai signifikansi sebesar 0,000, sedangkan untuk kelompok digital immigrant sebesar 0,240 dengan nilai signifikansi sebesar 0,005. Karena nilai signifikansi tersebut kurang dari 0,05 dan koefisien jalur bernilai positif maka dapat disimpulkan bahwa variabel perceived usefullness memiliki pengaruh yang positif terhadap behavioral intention to reuse mobile payment baik untuk kelompok digital native maupun kelompok digital immigrant, hasil tersebut menunjukkan bahwa semakin baik perceived usefullness maka semakin baik pula behavioral intention to reuse mobile payment. Dengan demikian H1a yang menyatakan "Perceived usefullness berpengaruh positif terhadap behavioral intention to reuse mobile payment" diterima. Hasil tersebut sejalan dengan penelitian sebelumnya yang dilakukan oleh Mun et al., (2017), Nguyen et al,. (2016), Koenig \& Lewis (2015), Phonthanukitithaworn et al., (2015) dan Guhr et al., (2013).

Hipotesis H1b menyatakan "Pengaruh perceived usefullness terhadap behavioral intention to reuse mobile payment pada Digital Native lebih kuat daripada Digital Immigrant" Berdasarkan hasil analisis diketahui nilai CR perceived usefullness terhadap behavioral intention to reuse mobile payment untuk kelompok digital native sebesar 3,366, sedangkan untuk kelompok digital immigrant sebesar 2,816. Karena nilai CR kelompok digital native lebih besar dari kelompok digital immigrant maka dapat disimpulkan bahwa pengaruh perceived usefullness terhadap behavioral intention to reuse mobile payment pada digital native lebih kuat daripada digital immigrant, dengan demikian hipotesis $\mathrm{H} 1 \mathrm{~b}$ diterima.

Hipotesis H2a menyatakan "Perceived ease of use berpengaruh positif terhadap perceived usefullness" Berdasarkan hasil analisis diketahui nilai estimasi koefisien jalur variabel perceived ease of use terhadap behavioral perceived usefullness untuk kelompok digital native sebesar 0,297 dengan nilai signifikansi sebesar 0,022, sedangkan untuk kelompok digital immigrant sebesar 0,257 dengan nilai signifikansi sebesar 0,035. Karena nilai signifikansi tersebut kurang dari 0,05 dan koefisien jalur bernilai positif maka dapat disimpulkan bahwa variabel perceived 
ease of use memiliki pengaruh yang positif terhadap perceived usefullness baik untuk kelompok digital native maupun kelompok digital immigrant, hasil tersebut menunjukkan bahwa semakin baik perceived ease of use maka semakin baik pula perceived usefullness. Dengan demikian hipotesis H2a diterima. Hasil tersebut sejalan dengan penelitian sebelumnya yang dilakukan oleh (Munoz et al., 2016).

Hipotesis H2b menyatakan "Perceived ease of use berpengaruh positif terhadap behavioral intention to reuse mobile payment. Berdasarkan hasil analisis diketahui nilai estimasi koefisien jalur variabel perceived ease of use terhadap behavioral intention to reuse mobile payment untuk kelompok digital native sebesar 0,218 dengan nilai signifikansi sebesar 0,005, sedangkan untuk kelompok digital immigrant sebesar 0,269 dengan nilai signifikansi sebesar 0,006. Karena nilai signifikansi tersebut kurang dari 0,05 dan koefisien jalur bernilai positif maka dapat disimpulkan bahwa variabel perceived ease of use memiliki pengaruh yang positif terhadap behavioral intention to reuse mobile payment baik untuk kelompok digital native maupun kelompok digital immigrant, hasil tersebut menunjukkan bahwa semakin baik perceived ease of use maka semakin baik pula behavioral intention to reuse mobile payment. Dengan demikian hipotesis H2b diterima. Hasil tersebut sejalan dengan penelitian sebelumnya yang dilakukan oleh Mun et al., (2017), Nguyen et al., Munoz at el., (2016) dan Guhr et al., (2013).

Hipotesis H2c menyatakan "Perceived ease of use berpengaruh positif terhadap trust". Berdasarkan hasil analisis diketahui nilai estimasi koefisien jalur variabel perceived ease of use terhadap trust untuk kelompok digital native sebesar 0,420 dengan nilai signifikansi sebesar 0,000, sedangkan untuk kelompok digital immigrant sebesar 0,236 dengan nilai signifikansi sebesar 0,012. Karena nilai signifikansi tersebut kurang dari 0,05 dan koefisien jalur bernilai positif maka dapat disimpulkan bahwa variabel perceived ease of use memiliki pengaruh yang positif terhadap trust baik untuk kelompok digital native maupun kelompok digital immigrant, hasil tersebut menunjukkan bahwa semakin baik perceived ease of use maka semakin baik pula trust. Dengan demikian hipotesis H2c diterima. Hasil tersebut sejalan dengan penelitian sebelumnya yang dilakukan oleh (Munoz et al., 2016).

Hipotesis H2d menyatakan "Pengaruh perceived ease of use terhadap behavioral intention to reuse mobile payment pada Digital Native lebih kuat daripada Digital Immigrant". Berdasarkan hasil analisis diketahui nilai CR perceived ease of use terhadap behavioral intention to reuse mobile payment untuk kelompok digital native sebesar 2,838, sedangkan untuk kelompok digital immigrant sebesar 2,768. Karena nilai CR kelompok digital native lebih besar dari kelompok digital immigrant maka dapat disimpulkan bahwa pengaruh perceived ease of use terhadap behavioral intention to reuse mobile payment pada digital native lebih kuat daripada digital immigrant, dengan demikian hipotesis $\mathrm{H} 2 \mathrm{~d}$ diterima.

Hipotesis H3a menyatakan "Trust berpengaruh positif terhadap perceived usefullness". Berdasarkan hasil analisis diketahui nilai estimasi koefisien jalur variabel trust terhadap behavioral perceived usefullness untuk kelompok digital native sebesar 0,432 dengan nilai signifikansi sebesar 0,001, sedangkan untuk kelompok digital immigrant sebesar 0,263 dengan nilai signifikansi sebesar 0,038. Karena nilai signifikansi tersebut kurang dari 0,05 dan koefisien jalur bernilai positif maka dapat disimpulkan bahwa variabel trust memiliki pengaruh yang positif terhadap perceived usefullness baik untuk kelompok digital native maupun kelompok digital immigrant, hasil tersebut menunjukkan bahwa semakin baik trust maka semakin baik pula perceived usefullness. Dengan demikian hipotesis H3a diterima. Hasil tersebut sejalan dengan penelitian sebelumnya yang dilakukan oleh Li et al., (2007).

Hipotesis H3b menyatakan "Trust berpengaruh positif terhadap behavioral intention to reuse mobile payment". Berdasarkan hasil analisis diketahui nilai estimasi koefisien jalur variabel trust terhadap behavioral intention to reuse mobile payment untuk kelompok digital native sebesar 0,246 dengan nilai signifikansi sebesar 0,012, sedangkan untuk kelompok digital immigrant sebesar 0,236 dengan nilai signifikansi sebesar 0,032. Karena nilai signifikansi tersebut kurang dari 0,05 dan koefisien jalur bernilai positif maka dapat disimpulkan bahwa variabel trust 
memiliki pengaruh yang positif terhadap behavioral intention to reuse mobile payment baik untuk kelompok digital native maupun kelompok digital immigrant, hasil tersebut menunjukkan bahwa semakin baik trust maka semakin baik pula behavioral intention to reuse mobile payment. Dengan demikian hipotesis H3b diterima. Hasil tersebut sejalan dengan penelitian sebelumnya yang dilakukan oleh Nguyen et al., (2016) dan Phonthanukitithaworn et al., (2015).

Hipotesis H3c menyatakan "Pengaruh trust terhadap behavioral intention to reuse mobile payment pada Digital Native lebih kuat daripada Digital Immigrant". Berdasarkan hasil analisis diketahui nilai CR trust terhadap behavioral intention to reuse mobile payment untuk kelompok digital native sebesar 2,523, sedangkan untuk kelompok digital immigrant sebesar 2,140. Karena nilai CR kelompok digital native lebih besar dari kelompok digital immigrant maka dapat disimpulkan bahwa pengaruh trust terhadap behavioral intention to reuse mobile payment pada digital native lebih kuat daripada digital immigrant, dengan demikian hipotesis $\mathrm{H} 3 \mathrm{c}$ diterima.

Hipotesis H4a menyatakan "Perceived risk berpengaruh negatif terhadap trust". Berdasarkan hasil analisis diketahui nilai estimasi koefisien jalur variabel perceived risk terhadap trust untuk kelompok digital native sebesar -0,492 dengan nilai signifikansi sebesar 0,000, sedangkan untuk kelompok digital immigrant sebesar -0,371 dengan nilai signifikansi sebesar 0,000. Karena nilai signifikansi tersebut kurang dari 0,05 dan koefisien jalur bernilai negatif maka dapat disimpulkan bahwa variabel perceived risk memiliki pengaruh yang negatif terhadap trust baik untuk kelompok digital native maupun kelompok digital immigrant, hasil tersebut menunjukkan bahwa semakin tinggi perceived risk maka akan menurunkan trust. Dengan demikian hipotesis H4a diterima. Hasil tersebut sejalan dengan penelitian sebelumnya yang dilakukan oleh Koenig \& Lewis (2015) dan Phonthanukitithaworn et al., (2015).

Hipotesis H4b menyatakan "Perceived risk berpengaruh negatif terhadap behavioral intention to reuse mobile payment". Berdasarkan hasil analisis diketahui nilai estimasi koefisien jalur variabel perceived risk terhadap behavioral intention to reuse mobile payment untuk kelompok digital native sebesar -0,331 dengan nilai signifikansi sebesar 0,000, sedangkan untuk kelompok digital immigrant sebesar -0,311 dengan nilai signifikansi sebesar 0,001. Karena nilai signifikansi tersebut kurang dari 0,05 dan koefisien jalur bernilai negatif maka dapat disimpulkan bahwa variabel perceived risk memiliki pengaruh yang negatif terhadap behavioral intention to reuse mobile payment baik untuk kelompok digital native maupun kelompok digital immigrant, hasil tersebut menunjukkan bahwa semakin tinggi perceived risk maka akan menurunkan behavioral intention to reuse mobile payment. Dengan demikian hipotesi $\mathrm{H} 4 \mathrm{~b}$ diterima. Hasil tersebut sejalan dengan penelitian sebelumnya yang dilakukan oleh Luo et al., (2010).

Hipotesis H4c menyatakan "Pengaruh perceived risk terhadap behavioral intention to reuse mobile payment pada Digital Native lebih kuat daripada Digital Immigrant". Berdasarkan hasil analisis diketahui nilai CR perceived risk terhadap behavioral intention to reuse mobile payment untuk kelompok digital native sebesar -4,138, sedangkan untuk kelompok digital immigrant sebesar -3,214. Karena nilai CR kelompok digital native lebih besar dari kelompok digital immigrant maka dapat disimpulkan bahwa pengaruh perceived risk terhadap behavioral intention to reuse mobile payment pada digital native lebih kuat daripada digital immigrant, dengan demikian hipotesis H4c diterima.

Hipotesis H5a menyatakan "Social influence berpengaruh positif terhadap behavioral intention to reuse mobile payment". Berdasarkan hasil analisis diketahui nilai estimasi koefisien jalur variabel sosial influence terhadap behavioral intention to reuse mobile payment untuk kelompok digital native sebesar 0,151 dengan nilai signifikansi sebesar 0,006, sedangkan untuk kelompok digital immigrant sebesar 0,214 dengan nilai signifikansi sebesar 0,009. Karena nilai signifikansi tersebut kurang dari 0,05 dan koefisien jalur bernilai positif maka dapat disimpulkan bahwa variabel social influence memiliki pengaruh yang positif terhadap behavioral intention to reuse mobile payment baik untuk kelompok digital native maupun kelompok digital immigrant, hasil tersebut menunjukkan bahwa semakin baik sosial influence maka akan meningkatkan behavioral intention to reuse mobile payment. Dengan demikian hipotesis H5a diterima. Hasil tersebut 
sejalan dengan penelitian sebelumnya yang dilakukan oleh Koenig \& Lewis (2015); Mun et al., (2017).

Hipotesis H5b menyatakan "Pengaruh sosial influence terhadap behavioral intention to reuse mobile payment pada Digital Native lebih kuat daripada Digital Immigrant". Berdasarkan hasil analisis diketahui nilai CR social influence terhadap behavioral intention to reuse mobile payment untuk kelompok digital native sebesar 2,759, sedangkan untuk kelompok digital immigrant sebesar 2,622. Karena nilai CR kelompok digital native lebih besar dari kelompok digital immigrant maka dapat disimpulkan bahwa pengaruh social influence terhadap behavioral intention to reuse mobile payment pada digital native lebih kuat daripada digital immigrant, dengan demikian hipotesis H5b diterima.

\section{KESIMPULAN}

\section{Kesimpulan}

Perceived usefullness berpengaruh positif terhadap behavioral intention to reuse mobile payment, hal ini menunjukan bahwa baik pada generasi digital native maupun pada generasi digital immigrant mempersepsikan positif kegunaan atau manfaat dari penggunaan mobile payment yaitu berupa kecepatan transaksi, efektifitas, kecepatan sehingga mampu mempengaruhi sikap responden untuk menggunakan kembali mobile payment. Pengaruh perceived usefullness terhadap behavioral intention to reuse mobile payment pada digital native lebih kuat daripada digital immigrant, hal ini menunjukan bahwa generasi digital native yang lahir dan berkembang di era digital lebih merasakan manfaat dan kegunaan mobile payment dibandingkan generasi digital immigrant.

Perceived ease of use berpengaruh positif terhadap perceived usefullness, hal ini menunjukan bahwa baik pada generasi digital native maupun pada generasi digital immigrant mempersepsikan positif kemudahan penggunaan mobile payment sehingga mampu mempengaruhi kepercayaan responden. Perceived ease of use berpengaruh positif terhadap behavioral intention to reuse mobile payment, hal ini menunjukan bahwa baik pada generasi digital native maupun pada generasi digital immigrant mempersepsikan positif kemudahan penggunaan mobile payment sehingga mampu mempengaruhi sikap responden untuk menggunakan kembali mobile payment.

Perceived ease of use berpengaruh positif terhadap trust, hal ini menunjukan bahwa baik pada generasi digital native maupun pada generasi digital immigrant mempersepsikan positif kemudahan penggunaan mobile payment sehingga mampu mempengaruhi kepercayaan konsumen pada mobile payment. Pengaruh perceived ease of use terhadap behavioral intention to reuse mobile payment pada digital native lebih kuat daripada digital immigrant, hal ini menunjukan bahwa generasi digital native yang lahir dan berkembang di era digital lebih merasakan kemudahan pengunaan mobile payment dibandingkan generasi digital immigrant.

Trust berpengaruh positif terhadap perceived usefullness, hal ini menunjukan bahwa baik pada generasi digital native maupun pada generasi digital immigrant mempersepsikan positif trust (kepercayaan) pada produk mobile payment di Indonesia sehingga mampu mempengaruhi sikap responden terhadap persepsi kegunaan mobile payment. Trust berpengaruh positif terhadap behavioral intention to reuse mobile payment, hal ini menunjukan bahwa baik pada generasi digital native maupun pada generasi digital immigrant mempersepsikan positif trust (kepercayaan) pada produk mobile payment di Indonesia sehingga mampu mempengaruhi sikap responden untuk menggunakan kembali mobile payment. Pengaruh trust terhadap behavioral intention to reuse mobile payment pada digital native lebih kuat daripada digital immigrant, hal ini menunjukan bahwa generasi digital native yang lahir dan berkembang di era digital lebih yakin bahwa produk mobile payment di Indonesia akan memberikan kualitas yang terbaik dibandingkan generasi digital immigrant.

Perceived risk berpengaruh negatif terhadap trust, hal ini menunjukan bahwa baik pada generasi digital native maupun pada generasi digital immigrant mempersepsikan resiko mobile payment yang rendah sehingga mampu memberikan pengaruh positif terhadap kepercayaan pada mobile payment. Perceived risk berpengaruh negatif terhadap behavioral intention to reuse 
mobile payment, hal ini menunjukan bahwa baik pada generasi digital native maupun pada generasi digital immigrant mempersepsikan resiko mobile payment yang rendah sehingga mampu memberikan pengaruh positif terhadap sikap responden untuk menggunakan kembali mobile payment. Pengaruh perceived risk terhadap behavioral intention to reuse mobile payment pada digital native lebih kuat daripada digital immigrant, hal ini menunjukan bahwa generasi digital native yang lahir dan berkembang di era digital mempersepsikan rendah resiko yang terdapat pada mobile payment seperti resiko kehilangan uang, resiko saat pembayaran, resiko server yang kurang baik dan resiko privasi daripada generasi digital immigrant

Social influence berpengaruh positif terhadap behavioral intention to reuse mobile payment, hal ini menunjukan bahwa baik pada generasi digital native maupun pada generasi digital immigrant mempersepsikan positif social influence sehingga mampu mempengaruhi sikap responden untuk menggunakan kembali mobile payment. Pengaruh social influence terhadap behavioral intention to reuse mobile payment pada digital native lebih kuat daripada digital immigrant, hal ini menunjukan bahwa generasi digital native yang lahir dan berkembang di era digital lebih meraskan bahwa orang-orang terdekat seperti keluarga, teman dan pasangan serta lingkungan budaya sekitarnya memberikan pengaruh positif terhadap sikap responden untuk menggunakan kembali mobile payment.

\section{DAFTAR PUSTAKA}

Bank Indonesia. (2015). Statistik Metadata Sistem Pembayaran E-Money. [Online].http://www.bi.go.id/id/statistik/metadata/sistempembayaran/DocumentMeta dataEMoney.pdf. [22 September 2016].

Bank Indonesia. (2016). Payment System License Information. [Online] http://www.bi.go.id/en/sistempembayaran/informasiperizinan/uangelektronik/Conte nts/Default.aspx [13 Oktober 2016]

Dahlberg, T., Mallat, N. and Oorni, A. (2003). Trust Enhanced Technology Acceptance ModelConsumer Acceptance of Mobile Payment Solutions: Tentative Evidence. Stockholm Mobility Roundtable, Stockholm, pp. 22-23.

Davis, F. (1989). Perceived Usefulness, Perceived Ease of Use, and User Acceptance of Information Technology. MIS Quarterly (13:3),319-339.

Davis, F., Bagozzi, R., \& Warshaw, P. (1989). User Acceptance of Computer Technology: A Comparison of Two Theoretical Models. Management Science (35:8), 982-1002.

Davis, F., Bagozzi, R., \& Warshaw, P. (1992). Extrinsic and Intrinsic Motivation to Use Computers in The Worksplace. Journal of Applied Social Psychology (22:14), 1111-1132.

Djarwanto PS, dan Subagyo, Pangestu. (2005). Statistik Induktif. Edisi Kelima. BPFE. Yogyakarta.

Featherman, M. S., dan Pavlou, P. A. (2003). Predicting E-Services Adoption: A Perceived Risk Facets Perspective. International Journal of Human-Computer Studies, 59(4), 451-474

Gefen, D., dan Straub, D. W. (2004). Consumer Trust in B2C E-commerce and The Importance of Social Presence: Experiments in E-products and Eservices. Omega, 32(6), 407-424.

Guhr, N., Lou, T., Wiegard, R dan Breitner, M. (2013). Technology Readiness in Customers' Perception and Acceptance of Mobile Payment: An Empirical Study in Finland, Germany, the USA and Japan. 11th International Conference. Wirtschafts Informatik Proceedings. Jerman. 2013.

Jakpat. (2018). "Mobile Payment in Indonesia". Jakpat Free Survey Report.

Jogiyanto. (2007). Sistem Informasi Keperilakuan. Edisi Revisi. Andi Offset. Yogyakarta. 
Koenig, L., Marquet, M., Palmer, A dan Zhao, L. Enjoyment and Social Influence: Predicting Mobile Payment Adoption. (2015). The Service Industries Journal.

Lai, Y. H. (2012). The Study of Technology Acceptance For E-wallets Application of Clinic Fees Payment. Health Journal (1949-4998), 4(11).

Lee, T. (2005). The impact of perceptions of interactivity on customer trust and transaction intentions in mobile commerce. Journal of Electronic Commerce Research, 6(3), 165-180.

Li, R., Kim, J., dan Park, J. (2007). The Effects of Internet Shoppers' Trust on Their Purchasing Intention in China. Journal of Information Systems and Technology Management, 4(3), 269-286.

Lu, J., Yao, J. E., dan Yu, C. S. (2005). Personal Innovativeness, Social influences and Adoption of Wireless Internet Services Via Mobile Technology. The Journal of Strategic Information Systems, 14(3), 245-268.

Lu, Y., Yang, S., Chau, P. Y., dan Cao, Y. (2011). Dynamics Between The Trust Transfer Process and Intention To Use Mobile Payment Services: A Crossenvironment Perspective. Information \& Management, 48(8), 393-403.

Luo, X., Li, H., Zhang, J., dan Shim, J. P. (2010). Examining Multi-dimensional Trust and Multifaceted Risk in Initial Acceptance of Emerging Technologies: An empirical study of mobile banking services. Decision support systems, 49(2), 222- 234.

Malhotra, N. K., Kim, S. S., dan Agarwal, J. (2004). Internet Users' Information Privacy Concerns (IUIPC): The Construct, The Scale, and A Causal Model. Information Systems Research, 15(4), 336-355.

MasterCard,. "Mobile payments Readiness Index" (2012). [Online]. Available: http://mobilereadiness.mastercard.com/the-index/. 2012

MDI Ventures., dan Mandiri Sekuritas. "Mobile Payments in Indonesia: Race to Big Data Domination". 2017.

Moore, G., \& Benbasat, I. (1991). Development of an Instrument to Measure the Perceptions of Adopting an Information Technology Innovation. Information System Research (2:3), 192222.

Mun, P.Y., Khalid, H dan Nadarajah, D. (2017). Millennials' Perception on Mobile Payment Services in Malaysia. Procedia Computer Science 124.397-404

Munoz, F., Climent , S dan Cabanillas S. (2016). Determinants of Intention to Use the Mobile Banking Apps: An Extension of The Classic TAM Model. Spanish Journal of Marketing. SJME vol 14.

Nguyen, N., Cao, K., Dang, L., dan Nguyen A. (2016). Predicting Consumer Intention to Use Mobile Payment Services: Empirical Evidence from Vietnam. International Journal of Marketing Studies; Vol. 8, No. 1.

Nysveen, H., Pedersen dan Thorbjørnsen. (2005). Intentions to Use Mobile Services: Antecedents and Cross-Service Comparisons. Journal of the Academy of Marketing Science. Volume: 33 No: 3, 330-346

Pavlou, P. A., Liang, H., dan Xue, Y. (2007). Understanding and mitigating uncertainty in online exchange relationships: A principal-agent perspective. MIS Quarterly, 31(1), 105-136.

Phonthanukitithaworn, C. (2016). User Intentions to Adopt Mobile Payment Services: A Study of Early Adopters in Thailand. Journal of Internet Banking and Commerce. Vol. 20, no. 1.

Sangadji., Etta Mamang., dan Sopiah. (2013). Perilaku Konsumen : Pendekatan Praktis Disertai Himpunan Jurnal Penelitian. Edisi pertama. Andi Offset. Yogyakarta 
Shin, D. H. (2009). Towards an Understanding of The Consumer Acceptance of Mobile Wallet. Computers in Human Behavior, 25(6), 1343-1354.

Shin, D. H., dan Kim, W. Y. (2008). Applying The Technology Acceptance Model and Flow Theory to Cyworld User Behavior: Implication of The Web 2.0 User Acceptance. Cyber Psychology \& Behavior, 11(3), 378-382

Suliyanto. (2018). Metode Penelitian Bisnis. Andi Offset. Yogyakarta.

Suresh, A.M., dan Shashikala, R. (2011). Identifying Factors of Consumer Perceived Risk towards Online Shopping in India", IPEDR, 12, p.336-341.

Teo, H dan Pok, H. (2003). Adoption of the Internet and WAP-Enabled Phones in Singapore. Behaviour \& Information.Vol: 22, No: 4, 281-289

Venkatesh, V., \& Davis, F. (2000). A Theoritical Extension of the Technology Acceptance Model: Four Longitudinal Field Studies. Management Science (45:2), 186-204.

Venkatesh, V., Morris, M., Davis, G., \& Davis, F. (2003). User Acceptance of Information Technology: Toward a Unified View. MIS Quarterly (27:3), 425-478. 